Article

\title{
A Multidimensional Model of Sustainable Renewable Energy Linking Purchase Intentions, Attitude and User Behavior in Nigeria
}

\author{
Paul Chibuogwu Ashinze ${ }^{1, *}$, Jian Tian ${ }^{1, *}$, Peter Chiedu Ashinze ${ }^{2}$, Mehrab Nazir ${ }^{1} \oplus$ and Imrab Shaheen ${ }^{3}$ \\ 1 School of Economics and Management, Jiangsu University of Science \& Technology, Zhenjiang 212100, China; \\ Mehrabnazir9@gmail.com \\ 2 Department of Social and Cultural Anthropology, Faculty of Humanities, University of Cologne, \\ 50923 Cologne, Germany; ashinzechiedu@yahoo.com \\ 3 Department of Public Administration, University of Kotli Azad Jammu \&Kashmir, \\ Kotli 11100, AJK, Pakistan; imrabs@yahoo.com \\ * Correspondence: ashinzepaul@yahoo.com (P.C.A.); tianjian@just.edu.cn (J.T.)
}

check for

updates

Citation: Ashinze, P.C.; Tian, J.;

Ashinze, P.C.; Nazir, M.; Shaheen, I. A

Multidimensional Model of

Sustainable Renewable Energy

Linking Purchase Intentions, Attitude and User Behavior in Nigeria.

Sustainability 2021, 13, 10576.

https://doi.org/10.3390/su131910576

Academic Editors: Assunta Di Vaio and Theodore Syriopoulos

Received: 1 July 2021

Accepted: 11 August 2021

Published: 24 September 2021

Publisher's Note: MDPI stays neutral with regard to jurisdictional claims in published maps and institutional affiliations.

Copyright: (c) 2021 by the authors. Licensee MDPI, Basel, Switzerland. This article is an open access article distributed under the terms and conditions of the Creative Commons Attribution (CC BY) license (https:// creativecommons.org/licenses/by/ $4.0 /)$.

\begin{abstract}
This study investigates the challenges to Nigeria's renewable energy growth; specifically, it analyzes the factors that influence the intention to use renewable energy in Nigeria. This paper was based on the theory of planned behavior, the technology acceptance model, the unified theory of acceptance and use of technology, the diffusion of innovation theory, and previous studies on acceptance. The proposed hypotheses have been tested using structured questionnaires based on a sample of 500 Nigerian family heads. A structural equation modeling technique was used to analyze the relationships of the studied variables-relative advantage, ease of use, perceived behavioral control, subjective norm, awareness, cost, attitude, income, gender, age, and educationwith purchase intention. The study findings show that attitude has a significant mediating effect on the relationship between intention to use and determinants (relative advantage, subjective norm, perceived behavioral control, ease of use, cost and awareness) and no significant impact on the purchase intention of the control variables (income, education, age, and gender) in the structural model. The study's results support business decisions in the renewable energy sub-sector in Nigeria and other developing nations. Furthermore, the results of this study could serve as a reference for the government to make decisions concerning the implementation of renewable energy.
\end{abstract}

Keywords: renewable energy; attitude; purchase intention; use behaviors

\section{Introduction}

The increased demand for energy and the risk of depletion of the fossil fuels has led to an increased demand for the rapid development of renewable energy sources in order to meet clients' needs. Renewable energies entail the exploitation of natural energy flows (e.g., wings, sunlight, falling water, waves, tides, and ocean currents) or the exploitation of natural resources at a level equivalent to or higher than the human utilization rate (e.g., biofuels, ocean thermal gradients, and hydroelectric reservoirs) [1-3]. The concept refers to energy generated from sources whose supplies are regenerative and inexhaustible. The search for an alternative source of energy supply is increasing by the day. The world's growing population, climate change, and sustainable development seem to be significant drivers of renewable energy technologies. Global studies suggest a consensus on the significance of the renewable energy market, and by improving environmental performance and developing green products, companies improve their reputation $[2,4]$. However, it is essential to note that not all environmentally friendly goods successfully garner customer interest in the market. Therefore, RE marketing must overcome local marketing challenges to increase demand in various marketing contexts. Renewable energy could play a key role in providing sustainable energy to vast populations in less privileged 
countries (LDCs). However, despite the need for continuous growth in renewable energy development, some countries still have doubts about using these resources [5,6]. This applies to the Nigerian case, which has a large energy market; there seems to be low acceptance amongst consumers of renewable energy sources. Sub-Saharan Africa continues to be the lowest-ranked according to energy access, with just over $40 \%$ of Nigerians having access to electricity that is highly reliant on fossil fuels. Drivers of RE in Nigeria include economic growth, the urge to solve energy access problems and security, improved energy supplies, population, climate change, and the electrification of rural and grid-inaccessible areas [7]. Nigeria's total RE potential is not fully utilized, and electricity supply is far less than demand $[8,9]$. The critical role of public acceptance in the successful introduction of renewable energy infrastructures into society is well-established, especially in the advanced world $[10,11]$. Low acceptance could hamper the implementation of sustainable energy technologies, which hinders critical environmental goals and vice versa [12].

Several national policies have been introduced to promote the optimal utilization of Nigeria's energy resources (conventional and renewable) for sustainable development. These include the National Energy Policy [13] 2003, and the Renewable Energy Master Plan (NREMP) 2005, with high expectations regarding the active participation of the private sector [14,15]. The overall aim was to achieve $10 \%$ RE penetration by 2020 . However, minor or short-term results were achieved, and the results of these policies fall far short of Nigeria's renewable energy potential $[16,17]$. In recent years, there has been an increase in renewable energy installations across various world countries, at least at a small-scale level. However, Nigerian electricity consumers have low acceptance of green energy, hence our investigation of the factors that might be responsible for low consumer intention to purchase RE. Nigeria has participated in global movements against climate change; therefore, studying consumer behavior toward intention to use RE provides valuable insights both locally and internationally. The previous study attributed the lack of willingness to use small-scale renewable energy for household energy to a lack of consumer confidence, lack of adequate policy, low public awareness, prices, financing constraints, low community acceptance, a lack of skilled human resources, and weak technology dissemination strategies $[5,10,18,19]$. While personal views on the intention to use renewable energy have been well studied in developed countries, they have been neglected in developing trends $[20,21]$. In particular, the results of studies conducted in the industrialized world cannot be effectively generalized to developing nations [22] due to their very different social, cultural, economic, political, and legal contexts [23]. Many scholars have worked on the Nigerian renewable energy market. Some consider the people's perception of RE technologies, while others studied extensively the potentials, policies, constraints, and current generation capacities. Few studies have concentrated on the individual's opinion of RE in Nigeria. To date, no detailed study has been targeted directly at the households, their socio-economic perceptions, and their intention to purchase RE technologies. There are few studies on the motivations behind intention to purchase, and actual demand remains very low. As such, the major factors affecting people's intention to use RE have not been fully evaluated in Nigeria. These factors may vary across technologies or countries. This study focuses on the factors in Nigeria, and aims to examine them in relation to intention to use renewable energy. The question imposed is "What are the factors that drive consumers" RE purchase intention in Nigeria?" Thus, the study aims to investigate factors that explain consumer intention to purchase RE technologies. This study presents the argument of factors influencing intention to purchase RE technologies, and the results will be beneficial to stakeholders. The findings will provide evidence and proof of the underlying motives for investing in RE in households. Furthermore, a proper evaluation of intention to purchase RE technologies will help stakeholders when making investment decisions, and in the development of products and market strategies. Factors such as relative advantages, cost, subjective norms, ease of use, awareness, attitude, perceived behavioral control, as well as age, gender, income and education, were chosen for testing. Because it is crucial for developing countries to understand the processes involved in the shift from conventional 
to renewable energy, this study focuses on factors and theories relevant to pre-purchase intention to use renewable energy.

Finally, although the study was conducted in a particular geographical area (Nigeria), these findings pertain to consumers' intention-based variables in acquiring and using RE, as Nigeria has a multitude of renewable energy sources, such as solar, wind, biomass, geothermal, and hydroelectric electricity. With such numerous renewable energy sources, the nation can satisfy $100 \%$ of its present and future energy demands if they are properly exploited. However, Nigeria is a developing nation that is not well-known for its renewable energy support, due to various difficulties and hurdles, including economic, regulatory, technical, and social constraints [24]. Nigeria's economy cannot bear such a load. As a result, the nation faces a serious energy crisis [25]. Furthermore, Nigerian society is interlinked, implying that the actions of peers, relatives, and neighbors have a major effect on the views of residents [25]. As a result, individuals are concerned about their efficacy, neighbor involvement, and the advantages of RE. As a developing nation, it is expected that these new elements, coupled with the current energy problem, will occur in other emerging countries. Consequently, the study's findings are not case-specific, but are rather transferable to other nations, emphasizing the significance of the impact of surrounding variables on RE use. As a result, Nigeria could be seen as an example for other nations seeking to identify these phenomena. Furthermore, the findings of this study will assist other developing and rising economies in formulating plans and policies for RE deployment in their respective nations.

\section{Study Model and Hypothesis Development}

The effectiveness of renewable energy product categories or services on the market depends largely on the acceptance and/or rejection of customers, which is ascertained by purchase intentions. The intention could be defined as a person's plan, commitment, or decision to carry out an action or achieve a certain goal [26]. According to Azjen's TPB, a person's intention is the central factor to performing a given behavior. Customer purchase intention indicates a person's willingness to buy a specific product chosen after evaluating factors [27]. It is a self-conscious plan of whether or not to purchase a specific product after considering the individual aspects (e.g., personal experience, feelings, etc.) and extrinsic aspects, such as cost and benefit [28]. Intentions are meant to be impacted motivational factors affecting a behavior; they are indicators of how willing customers are to try, and how much commitment they intend to invest in executing the behavior [29]. It implies that an individual's intention to perform progresses to a particular behavior-the shift from meaning to action [29].

Evidence suggests that intention is a good predictor of renewable energy purchasing behavior, and is a critical factor in evaluating people's actual purchasing behavior [6,30,31]. The behavioral intention of adoption refers to the consumer's intention to use a potential product or service [31].

This study aims to understand the intention of consumers to use renewable power. Several dependent variables may affect purchase intention, which can be defined as the mind's ability to behave a certain way as a means to purchase [32]. This study uses the combination of UTAUT, TPB, TAM and DOI as the basis of its theory. Researchers in different areas and in renewable energy have applied and illustrated these concepts in order to understand the intent to use renewable technology $[6,30,31,33]$. Studies show that it is possible to project customer intentions to use renewable power with reasonable precision. The evaluated determinants include relative advantage, ease of use, perceived behavioral control, subjective norm, awareness, cost, attitude, income, and education. These constructs selected for analysis were drawn from the mentioned theories, and are deemed to influence purchase intention. The constructs tested are as follows: Relative advantage refers to the extent to which an innovative product is considered better than those before it or its closest substitute [34,35]. It is the degree to which an invention is considered superior to its predecessor [36]. Thus, it refers to the marginal advantage 
of using solar energy over conventional energy, which various factors could influence. Consumers recognize the use of renewable energies and other socio-economic advantages from an environmental viewpoint [31,37]. RE's low penetration could be due to its low relative advantage over simple and user-friendly power sources for some parts of the world. The relative advantage is guaranteed if the new system provides higher value, is developed based on local taste, and provides a substitution incentive if consumers wish to revert to a previous technology [38,39]. The greater the perceived relative value of renewable power, the higher the adoption rate.

Furthermore, some earlier studies suggest a relative advantage that indirectly affects the behavioral intention to use RE. Relative advantage specifically affects the attitude that mediates the relationship with the intention [6,40-42]. This study, therefore, argues that:

Hypothesis 1 (H1). The relative advantage has a positive and major effect on the attitude towards the customer's intention to buy.

Hypothesis 2 (H2). Relative advantage has a significant and positive impact on buyer intention to use renewable energy.

Subjective norms, SN, refer to an individual's impression that most people close to him think that a given behavior should or should not be performed, i.e., the perceived social influence to perform or not to perform [43]. It is the result of the conviction that the person should act in accordance with the behavior and the incentive to comply with other specific groups of people [44]. It is the extent to which a person perceives that close relative/friends believe they should use RE. SNs consist of two elements that interact: belief in other people's values, how one would like to see other people behave (normative beliefs), and negative or positive opinions on each belief (outcome assessments) [45]. Thus, SN is changes one's behavior through the influence of others. Studies reveal that SN strongly affects consumers' green purchase decision-making process [2,46-48]. The level of impact other people's perceptions have on the adoption of renewable resources can differ between individuals. This study argues that the consumer's intention to adopt renewable energy is affected by intimate relationships involving friends, relatives, academics, employers, coworkers, etc. This is anchored in the belief that people who can influence an individual could influence them to purchase renewable energy products. With this view, the following hypotheses are presented:

Hypothesis 3 (H3). Subjective norms have a significant and robust effect on the attitude towards customers' intention to buy.

Hypothesis 4 (H4). Subjective norms have a significantly positive impact on the intention of consumers to buy renewable energy sources.

Perceived behavioral control (PBC) is the impression of the easiness or difficulty of performing a specific behavior, i.e., the degree to which a person believes that the behavior in question is enacted or not performed within his $\backslash$ her volitional control [28,49]. Studies show that individuals' behavior is greatly affected by their confidence in their ability to perform it. The literature demonstrates that PBC is a key factor in determining behavioral intent, which has a substantial effect on the self-efficacy of a specific behavior, including renewable energy [32,50,51]. The theory of planned behavior posits that individuals regulate their behavior, and thus, buying decision is a matter of individual convictions. PBC focuses on how much influence the individual has over the behavior, and how confident they feel about engaging or not engaging in it. The higher PBC a consumer has over using renewable energy, the more likely they are to adopt it, and vice versa [31]. Factors (situational and internal) considered by consumers include, but are not limited to, cost, changes in living standards, and other socio-economic parameters [52].

The following hypothesis is therefore given: 
Hypothesis 5 (H5). Higher PBC has a significant positive impact on the attitude towards customer purchasing intention.

Hypothesis 6 (H6). Higher perceived behavioral control has a significantly positive effect on the intention to use renewable power.

The degree to which a technology is believed to be challenging to use is referred to as perceived ease of use [49]. Perceived ease of use refers to the degree to which an individual presumes that a particular system would be convenient to use [53], i.e., the degree to which a new advancement in technology has been easily understood, operated, and managed by users [31]. Energy sources considered to be relatively easy to use and affordable would usually have higher market penetration. Researchers have discovered that renewable energy, such as solar energy, poses numerous technical barriers to users $[2,54,55]$. Renewable energy's installation, use, maintenance, and technicalities shape opinion concerning it. Simple to install, user-friendly and family-friendly renewable energy technologies that are beneficial to living standards are more likely to positively affect intent to adopt [56]. Producers could enhance ease of use if there is a clear understanding of the target markets' living standards, if they employ effective quality control, and if they ensure usage policy is easy to understand [43,57-59].

Hypothesis 7 (H7). Perceived ease of use significantly affects the attitude towards the customers' intention to purchase.

Hypothesis 8 (H8). Perceived ease of use has a strong positive effect on customers' intention to purchase renewable power.

The cost of renewable energy includes initial installation, maintenance, and the opportunity cost of adopting RE. This study has demonstrated that costs were also crucial in limiting the deployment and development of renewable energy solutions, particularly in developing nations with low per capita incomes [60]. This is mostly because the minimal level of capital needed for installing renewable power is usually higher than the minimum required for traditional energy. Several studies have discovered a direct and consequential link between cost and technology adoption [61,62]. Consumers will usually make a comparison of the potential benefits derived when adopting an RE technology with its perceived total cost. The higher the perceived cost, the lower its market value and the lower its usage rate [56]. Buyers will more likely develop stronger and more positive purchase intentions towards RE if the benefit-cost ratio high. The lower the perceived costs, the higher the rate of adoption of renewable energy, and vice versa.

Hypothesis 9 (H9). Cost has a negative effect on the attitude towards the intention of customers to buy.

Hypothesis 10 (H10) Cost has a negative and significant effect on the intention of consumers to purchase.

Awareness is the degree to which individuals are knowledgeable of modern technology, its advantages and disadvantages, and whether they can keep abreast of new emerging technology updates [31]. Awareness involves prospective customers being able to access sufficient details on RE's basic usage, economic opportunities, and environmental impacts [58]. Awareness is one major component of UTAUT that directly affects the behavioral intention to use renewable energy sources $[6,63,64]$. Our findings indicate that knowledge of a specific technology influences the interpretation of that technology's risks and benefits, including defining the potential impacts of the technology [65]. A higher awareness level is bound to increase the acceptability among new consumers of RE technologies [66]. 
Furthermore, knowledge of green products enables customers to build a positive awareness of RE marketing, and increase their interest in preventing environmental problems [67]. According to previous studies, most Nigerians are not well informed about environmental issues, and are unaware of how their behavior could reduce its impact [68]. Understanding consumer awareness is crucial to knowing how consumers make their purchasing decision concerning RE. Consumers' low use of RE in Nigeria may result from a lack of awareness (availability of products and added value). Consumers with more information about environmental degradation and its impacts on society will normally think they need to do something about it, and might consider purchasing RE $[69,70]$. Practically, the more knowledge people have, the better their awareness and the greater their intention to buy new clean energy technologies. The presence of an information gap or a lack of information negatively influences RE purchase behavior.

Hypothesis 11 (H11). Low awareness has a negative effect on the attitude towards the intention of the buyer to purchase.

Hypothesis 12 (H12). High awareness has a profound positive influence on intention to use renewable energy.

Attitude refers to the positive or negative feelings of a person about performing a target behavior [42]. It concerns personal views or behaviors towards an object, often in an evaluative way [71]. Attitude towards a behavior implies a positive or negative subjective assessment of an individual's behavior's consequences [72], which defines how individuals respond to that behavior [72]. The theory of planned behavior proves that the person's attitude towards a particular technology is the strongest predictor of the intent of the person to use that technology [32]. A higher attitude towards adopting renewable energies leads to the formation of intention, and eventually adoption. A person who has a positive attitude toward renewable power feels pressure to adopt it, and is likely to establish a purchasing intention. Some studies identified attitude as a key predictor of pro-environmental behavior, such as using renewable energy [63,73-75]. However, some authors opined the mediating role of attitude in predicting consumer RE behavior $[6,33,76]$, based on the idea that attitude is a first-stage mediator between other factors and intention.

This study seeks to further explore this concept by analyzing the mediator's role in the relationship between variables: relative advantage, ease of use, subjective norms, awareness, PBC, cost, and intention to use, in the context of an ideal model. The following hypotheses were thus tested:

Hypothesis 13 (H13). Attitude acts as a mediator between the intention to use renewable energy and its use variables.

Hypothesis 14 (H14). Intention to use mediates the relationship between use of behavior and determinants of renewable energy use.

Several studies have shown social and economic factors as essential in relation to primary determinants and behavioral intention [42]. This study posits that the demographic factors of age, gender, education, and income control the relationship between the selected variables and purchase intention. A survey on the buying of domestic energy-efficient and renewable power facilities in China showed that households' incomes positively moderate the interaction between purchasing attitude and intention, and incentives in the form of subsidies are more likely to enhance purchasing [77]. High-income and trained professionals have shown they are more likely to pay for clean energy, and young people are more supportive of renewable power adoption $[78,79]$. Some studies have also highlighted the impact of gender on the adoption of renewable energy, i.e., males imvested more than females in adopting renewable energy in Kaohsiung and Pingtung, Malaysia. [33] However, women in LA, USA showed much higher tendencies than men in terms of green buying 
and ecological attitudes $[80,81]$. While studies show the influence of socio-economic factors, income has not been found to impact the adoption of renewable energy [33] significantly. This study posits that the level of control or influence of socio-economic factors may vary depending on many factors according to the individual environment. To investigate this perspective in Nigeria, the following hypotheses were formulated:

Hypothesis 15 (H15). There is a strong positive relationship between high-income and purchase intention.

Hypothesis 16 (H16). There is no significant relationship between age and purchase intention for renewable energy.

Hypothesis 17 (H17). There is no significant relationship between gender and purchase intention.

Hypothesis 18 (H18). There is a significant relationship between high education and purchase intention.

RE purchase intention's conceptual framework would depend on various considerations, such as country, users, investors, goals, study problems and objectives, etc. [81]. The conceptual framework for this study is presented below Figure 1.

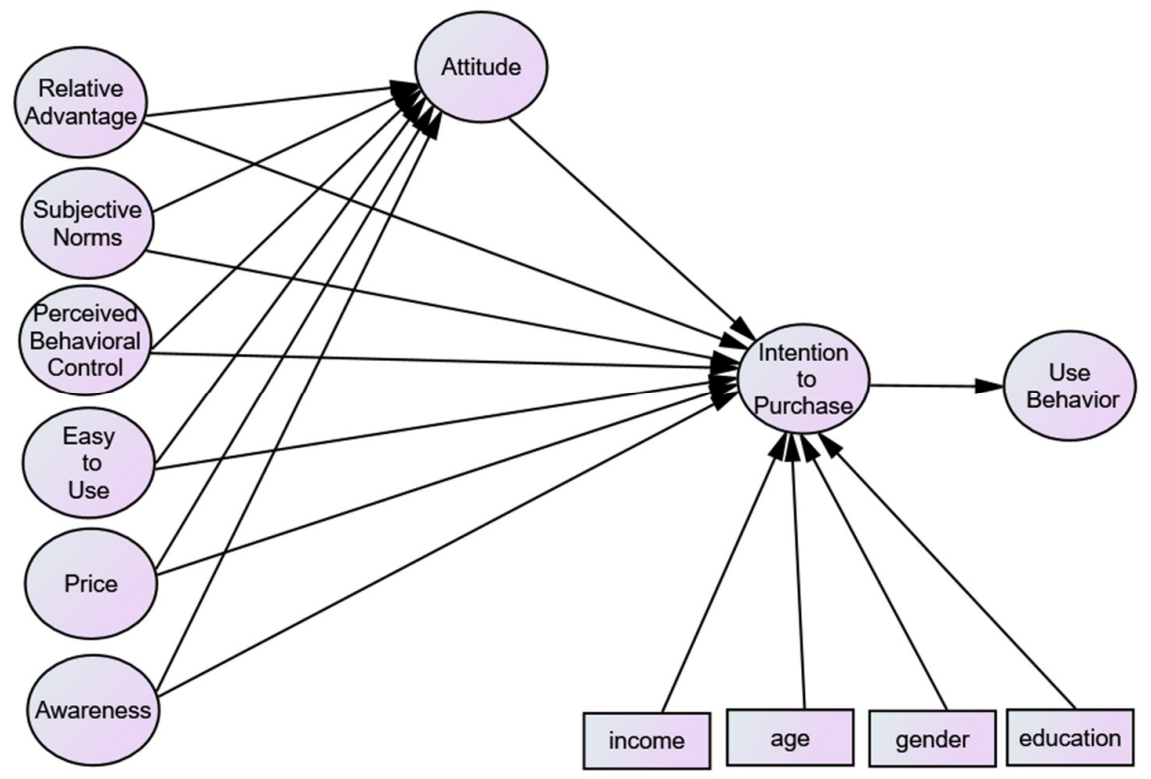

Figure 1. Study framework.

\section{Materials and Methods}

Study methodology plays a crucial role in achieving study objectives. The study design and data sampling and collection methods used in this study are presented in this section. Nigeria was the study site. The study was concerned with Lagos State residents. The reason for choosing Lagos is that it has the maximum population density, with the right mix of rich and poor, educated and uneducated, etc.

Moreover, Lagos is the most economically significant state in the country. Lagos State is split into five administrative regions, which are further divided into 20 local governments of the LGA area. This study used the multi-stage sampling technique. Firstly, two LGAs were randomly selected. In the second step, we used the random cluster sampling method for 20 villages/towns/cities from the two LGAs selected for the study. Solar energy has been Nigeria's most explored renewable energy source; thus, this study concentrates mainly on solar energy, while preparing further studies on other renewable energy sources. 
A structured questionnaire was used for data collection from heads of households through online channels (WhatsApp and email) and physically. The responses were gathered from heads of households from selected villages based on proportional allocation. A total of 520 questionnaires were received, and we considered 500 (after extracting the missing data) for a sufficiently accurate evaluation of the $C \alpha$ coefficient and structural equation modeling [82]. Moreover, the sample size for data analysis was determined based on a 95\% confidence interval and 5\% margin of error. The low margin of error was used because of online data collection. The structured questionnaire was based on different sections linking to the respondents' demographic profiles and questions to measure the intention of using RE-relative advantage, ease of use, perceived behavioral control, subjective norm, awareness, cost, attitude, income, and education. We used a five-point Likert scale from 1 to 5 , as follows: $1=$ strongly disagree; $2=$ disagree; $3=$ neither agree nor disagree; $4=$ agree; and $5=$ strongly agree. We added one section to the questionnaire to examine the use of RE. We measured the level of RE use by households to determine the substantial potential of energies-viz., solar energy.

Social factors are very significant in social science studies. All these factors are evaluated to verify the substantial direct impact of these control variables on purchase intention. The study also added some statistical variables, such as gender, income, age, and education. These components were obligatory for our purposes. The variables are detailed in Table 1.

Table 1. Demographics.

\begin{tabular}{cccc}
\hline Variable & Category & Frequency & Percentage \\
\hline \multirow{2}{*}{ Gender } & Male & 351 & 70.2 \\
& Female & 149 & 29.8 \\
\hline \multirow{3}{*}{ Age } & $20-30$ & 101 & 20.2 \\
& $31-40$ & 145 & 29 \\
& $41-50$ & 108 & 21.6 \\
& $51-60$ & 84 & 16.8 \\
& 61-above & 62 & 12.4 \\
\hline \multirow{3}{*}{ Qualification } & Bachelors & 114 & 22.8 \\
& Masters & 192 & 38.4 \\
& Postgraduates & 132 & 26.4 \\
& Diplomas & 51 & 10.2 \\
& Others & 11 & 2.2 \\
\hline \multirow{2}{*}{ Icome } & $1-10,000$ & 48 & 9.6 \\
& $10,000-20,000$ & 99 & 19.8 \\
& $20,000-30,000$ & 165 & 33.0 \\
& $30,000-40,000$ & 113 & 22.6 \\
& $40,000-$ above & 75 & 15.0 \\
\hline
\end{tabular}

A list of measured items and the sources of each part are presented separately in Table 2. The collected data were coded and modeled using IBM AMOS/SPSS Software. To test the hypotheses, a two-staged process was employed. Firstly, we used confirmatory factor analysis with maximum likelihood estimation to assess the model fit and examine the constructs' validity and reliability. We checked multi-regression and mediation in the second process to check the variables' direct and indirect relationships. We used bootstrapping for the mediation/indirect hypothesis (Preacher and Hayes, 2008). 
Table 2. Measures and items.

\begin{tabular}{ccc}
\hline Measures & Items & Source \\
\hline Attitude & 3 & {$[83]$} \\
Relative advantages & 5 & {$[84]$} \\
Subjective norms & 3 & {$[85]$} \\
Perceived behavioral control & 3 & {$[86]$} \\
Easy to use & 4 & {$[84]$} \\
Awareness & 5 & {$[87]$} \\
Perceived price/cost & 5 & {$[88]$} \\
Purchase intention & 3 & {$[89]$} \\
Use behavior & 4 & {$[85]$} \\
\hline
\end{tabular}

\section{Measurement Model}

Confirmatory factor analysis with maximum likelihood estimation was performed using Amos 20.0 to test the fitness measurement model. CFA developed a satisfactory fit with Chi-square (1596.798) and degree of freedom $524(p<0.001)$. A substantial Chi-square will be particularly susceptible to sample size [90]. Consequently, other model fit measures were also evaluated, as proposed by [91]. Indices and their scores are described in Table 3.

Table 3. Confirmatory factor analysis.

\begin{tabular}{lcl}
\hline & Overall Fit Index of the CFA Model \\
\hline Fit Index & Score & $\begin{array}{l}\text { Recommended Threshold } \\
\text { Value }\end{array}$ \\
\hline Absolute fit measures & & $\leq 2 \mathrm{a} ; \leq 5 \mathrm{~b}$ \\
CMIN/df & 2.821 & $\geq 0.90 \mathrm{a} ; \geq 0.80 \mathrm{~b}$ \\
GFI & 0.861 & $\leq 0.8 \mathrm{a} ; \leq 0.10 \mathrm{~b}$ \\
RMSEA & 0.059 & $\geq 0.90 \mathrm{a}$ \\
Incremental fit measures & & $\geq 0.90 \mathrm{a} ; \geq 0.80 \mathrm{~b}$ \\
NFI & 0.828 & $\geq 0.90 \mathrm{a}$ \\
AGFI & 0.833 & The higher the better \\
CFI & 0.957 & \\
SRMR & 0.026 &
\end{tabular}

\section{Reliability and Validity}

Table 4 shows the construct validity, reliability, and goodness of fit; discriminant and convergent validity were also evaluated through CFA. The value for the average variance extracted (AVE) should be $>0.50$. Thus, all the CFA values confirmed the convergent validity of the latent constructs. The square root of average conflict extracted and construct correlation was used to measure the latent constructs' discriminant validity. The values for the square root of AVE and the correlation are in and below the diagonals, which confirms the discriminant validity. Reference [91] suggested that the internal consistency (Reliability) is also one of the measures of convergent validity. To measure the internal consistency of latent variables, Cronbach's alpha was used. The CR was calculated; the value for CR should be greater than 0.7. All values were above the threshold. 
Table 4. Reliability and validity analysis.

\begin{tabular}{|c|c|c|c|c|c|c|c|c|c|c|c|c|c|}
\hline & CR & AVE & MSV & $\operatorname{MaxR}(H)$ & RLA & BRA & PRI & ITU & ACB & SUN & ATT & INT & PBC \\
\hline RLA & 0.971 & 0.870 & 0.229 & 0.977 & 0.933 & & & & & & & & \\
\hline BRA & 0.969 & 0.864 & 0.176 & 0.972 & $0.334^{* * *}$ & 0.929 & & & & & & & \\
\hline PRI & 0.946 & 0.778 & 0.176 & 0.953 & $0.385 * * *$ & $0.419^{* * *}$ & 0.882 & & & & & & \\
\hline ITU & 0.946 & 0.813 & 0.065 & 0.954 & $0.164^{* * *}$ & $0.163^{* * *}$ & $0.186^{* * *}$ & 0.902 & & & & & \\
\hline $\mathrm{ACB}$ & 0.956 & 0.845 & 0.294 & 0.960 & $0.478^{* * *}$ & $0.402 * * *$ & $0.376^{* * *}$ & $0.199^{* * *}$ & 0.919 & & & & \\
\hline SUN & 0.974 & 0.925 & 0.309 & 0.974 & $0.338^{* * *}$ & $0.241^{* * *}$ & $0.323^{* * *}$ & $0.243^{* * *}$ & $0.421^{* * *}$ & 0.962 & & & \\
\hline ATT & 0.941 & 0.842 & 0.248 & 0.947 & $0.357^{* * *}$ & $0.137^{* *}$ & $0.080^{\dagger}$ & $0.234^{* * *}$ & $0.382 * * *$ & $0.498^{* * *}$ & 0.917 & & \\
\hline INT & 0.938 & 0.834 & 0.294 & 0.947 & $0.411^{* * *}$ & $0.299^{* * * *}$ & $0.326^{* * *}$ & $0.256^{* * *}$ & $0.542 * * *$ & $0.446^{* * *}$ & $0.457^{* * *}$ & 0.913 & \\
\hline PBC & 0.902 & 0.755 & 0.309 & 0.919 & $0.406^{* * *}$ & $0.355^{* * *}$ & $0.415 * * *$ & $0.209 * * *$ & $0.443^{* * *}$ & $0.556^{* * *}$ & $0.350 * * *$ & $0.451^{* * *}$ & 0.869 \\
\hline
\end{tabular}

Note: $\mathrm{RLA}=$ relative advantage, $\mathrm{BRA}=$ awareness, $\mathrm{PRI}=$ price, $\mathrm{ITU}=$ easy to use, $\mathrm{ACB}=$ actual behavior, $\mathrm{SUN}=$ subjective norms, ATT $=$ attitude, $\mathrm{INT}=$ intention to purchase, $\mathrm{PBC}=$ perceived behavioral control. Significance of correlations: ${ }^{+} p<0.100, p<0.050$, ${ }^{* *} p<0.010,{ }^{* * *} p<0.001$.

\section{Structural Model}

Table 5 and Figure 2 show the proposed relationships between the studied variables in the structural model. Table 5 shows the $p$ values, parameter estimates, and critical rations of the constructs. H1 proposed that RLA has a positive and significant impact on ATT, and H2 proposed that SUN positively effects the ATT with values of $p<0.05$ and estimate $=0.333$. H3 stated that PBC positively relates to the ATT, with $p<0.05$ and estimate $=0.030$. H4 proposed the positive impact of ITU on ATT $(p<0.05$, estimate $=0.105)$. Meanwhile, H5 stated that PRI negatively relates to the ATT $(p<0.05$, estimate $=-0.149)$. The hypothesis H6 stated BRA negatively impacts the ATT, with $p<0.812$ and estimate $=-0.006$. The hypothesis H7 stated RLA positively impacts INT $(p<0.05$, estimate $=0.138)$. H8 claimed that SUN significantly and positively effects ATT $(p<0.05$ and estimate $=0.116)$. The hypothesis H9 stated that PBC positively impacts INT $(p<0.05$, estimate $=0.141)$. The hypothesis $\mathrm{H} 10$ stated that ITU is related positively to INT $(p<0.05$, estimate $=0.084)$. The hypothesis H11 claimed PRI and INT relate positively, with $p<0.05$ and estimate $=0.098$. H12 claimed BRA positively and significantly relates to INT $(p<0.812$, estimate $=0.075)$. H13 claimed that ATT positively effects INT $(p<0.05$, estimate $=0.298)$.

The hypothesis H14 stated that INT positively impacts INT $(p<0.05$, estimate $=0.547)$. The control variables (income, education, age, and gender) had no significant impact in the structural model on purchase intention.

Table 5. Proposed relationships in SEM.

\begin{tabular}{|c|c|c|c|c|c|c|c|}
\hline Hypotheses & Constructs & To & Constructs & Estimate & S.E. & C.R. & $p$ \\
\hline H1 & ATT & $<-$ & RLA & 0.197 & 0.029 & 6.765 & $* * *$ \\
\hline $\mathrm{H} 2$ & ATT & $<-$ & SUN & 0.333 & 0.030 & 11.145 & $* * *$ \\
\hline H3 & ATT & $<-$ & РBC & 0.072 & 0.030 & 2.388 & 0.017 \\
\hline H4 & ATT & $<-$ & ITU & 0.105 & 0.033 & 3.200 & 0.001 \\
\hline H5 & ATT & $<-$ & PRI & -0.149 & 0.028 & -5.221 & $* * *$ \\
\hline H6 & ATT & $<-$ & BRA & -0.006 & 0.026 & -0.238 & 0.812 \\
\hline H7 & INT & $<-$ & RLA & 0.138 & 0.033 & 4.142 & $* * *$ \\
\hline H8 & INT & $<-$ & SUN & 0.116 & 0.037 & 3.166 & 0.002 \\
\hline H9 & INT & $<-$ & PBC & 0.141 & 0.033 & 4.232 & $* * *$ \\
\hline H10 & INT & $<-$ & ITU & 0.084 & 0.036 & 2.316 & 0.021 \\
\hline H11 & INT & $<-$ & PRI & 0.098 & 0.032 & 3.046 & 0.002 \\
\hline H12 & INT & $<-$ & BRA & 0.075 & 0.029 & 2.576 & 0.010 \\
\hline H13 & INT & $<-$ & ATT & 0.298 & 0.050 & 5.954 & $* * *$ \\
\hline H14 & $\mathrm{ACB}$ & $<-$ & INT & 0.547 & 0.042 & 13.090 & $* * *$ \\
\hline \multirow{2}{*}{\multicolumn{8}{|c|}{$\begin{array}{c}\text { Control } \\
\text { Variables }\end{array}$}} \\
\hline & & & & & & & \\
\hline & INT & $<-$ & Gender & -0.079 & 0.162 & -0.486 & 0.627 \\
\hline & INT & $<-$ & Age & -0.038 & 0.045 & -0.852 & 0.394 \\
\hline & INT & $<-$ & Education & -0.101 & 0.042 & -2.430 & 0.015 \\
\hline & INT & $<-$ & Income & 0.037 & 0.052 & 0.711 & 0.477 \\
\hline
\end{tabular}

Note: $\mathrm{RLA}=$ relative advantage, $\mathrm{BRA}=$ awareness, $\mathrm{PRI}=$ price, $\mathrm{ITU}=$ easy to use, $\mathrm{ACB}=$ actual behavior, $\mathrm{SUN}=$ subjective norms, $\mathrm{ATT}=$ attitude, $\mathrm{INT}=$ intention to purchase, $\mathrm{PBC}=$ perceived behavioral control, ${ }^{* * *} p<0.001$. 


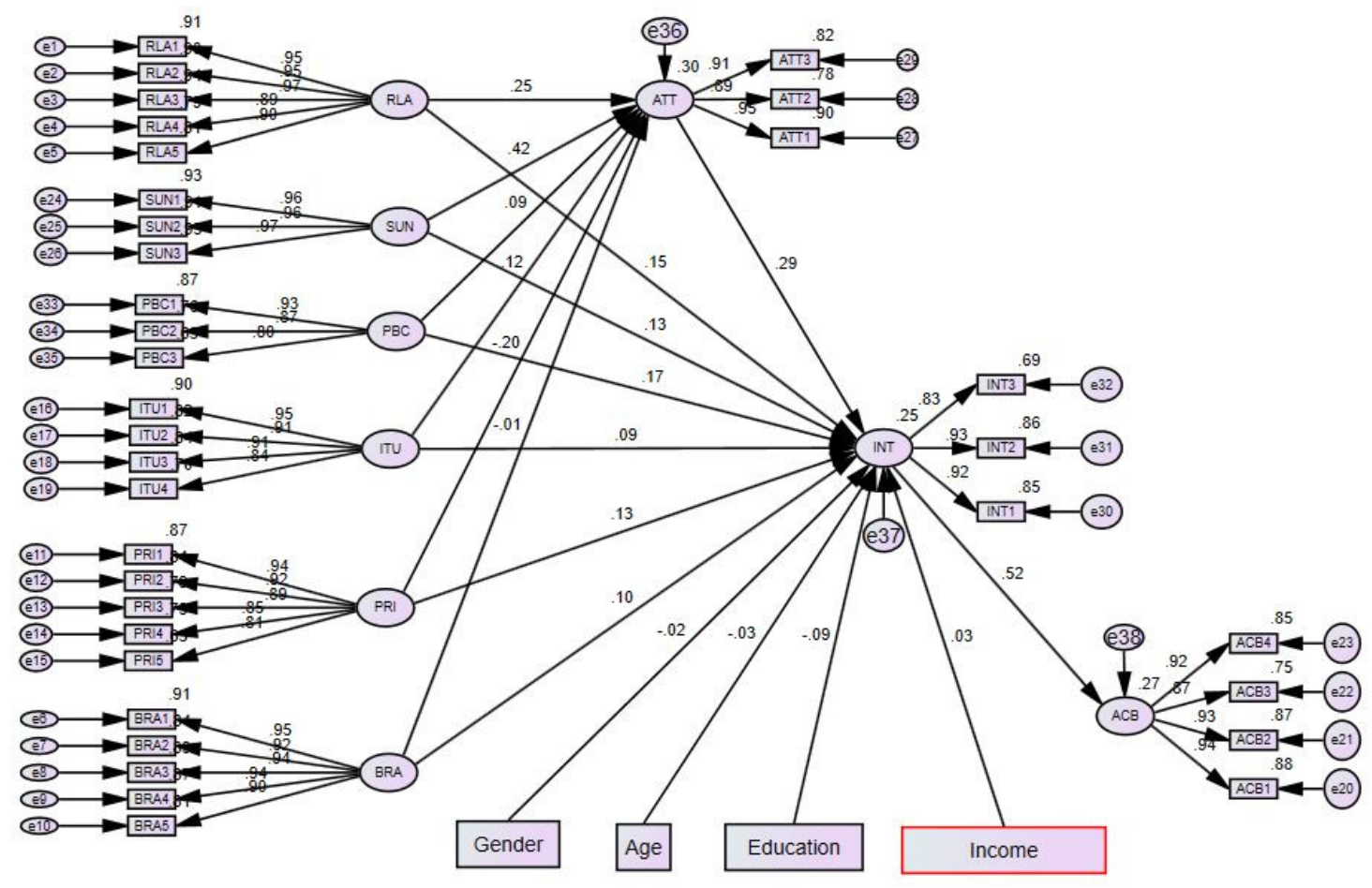

Figure 2. Mediating effect.

\section{Discussions}

Given the importance of RE as a sustainable source of clean energy and its determinants on the one hand, and the attitudes that mediate the relation between RE and intention towards use behavior on the other hand, this study aimed at studying the factors affecting the intention towards use behavior of RE in Nigeria. According to the outcome, hypothesis 1 is supported, and there exists a significant direct relationship between relative advantage and attitude. This means that the higher the perceived relative advantage of renewable energy, the higher the rate of adoption. However, some previous studies supported the hypothesis that relative advantage directly influences individual attitude to use RE [6,40-42]. According to the result of hypothesis 2, this is supported. There is a significant direct relationship between the subjective norms and attitudes towards purchase intention and use behavior of RE. Individuals in Nigeria have high opinions of adopting renewable energy, but these may vary from one person to another. As such, this hypothesis argued that intention to purchase renewable energy is potentially influenced by close subjective norms, such as friends, family, educators, employers, and professional colleagues.

The result of hypothesis 3 showed that PBC has a significant positive relationship with customers' attitudes toward purchase intention and use of RE. However, this result also supported the theory of planned behavior. This hypothesis pertains to the individual's perception of his influence over behavior, and it represents the instigators of and obstacles before the success of a specific behavior. In this case, If Nigeria's consumers have sufficient financial funds to purchase RE and technology, they can use these advanced renewable resources to demonstrate greater self-efficacy and confidence. Most villagers live with relatively low incomes, so the government should financially help individuals to purchase RE. Hypothesis 4 is supported, showing that perceived ease of use directly significantly influences attitude towards purchase intention. According to this result, individuals in Nigeria believed that this technology is straightforward to understand, operate, and maintain. A renewable energy system that is easy to install, user-friendly, family-friendly, and beneficial to the standard of living will more likely positively influence the intention to adopt RE. This would enhance the use behavior of customers. Based on the outcomes, 
hypothesis 5 is supported, and there exists a negative relationship between the perceived cost of RE and attitude towards purchase intention and use of RE.

The perceived cost of any product is considered an essential element in the adoption of the product. So, the cost of renewable energy contains initial installation process costs, maintenance costs, and the opportunity cost of adopting the RE. Consumers will typically equate the possible benefits resulting from RE technology's introduction with its perceived overall costs. The higher the perceived value, the lower its value to consumers, and the lower its ease of consumption; the lower the quality, the higher the price of adoption of renewable energy. According to the given results of Table 6 and Figure 2, the outcomes of all mediating variables (hypotheses 7, 8, 9, 10 and 11) indicated that attitude has a positive significant mediating effect in the relationship between intention to use and determinants (relative advantage, subjective norm, perceived behavior control, easy to use, cost and awareness) of renewable energy. In general, following the attitude component's inclusion as a mediating variable in the study, the model's predictive capacity is substantially improved. Intention to purchase plays an essential role in mediating influences between the determinants of renewable energy and use behavior. The result of hypothesis 14 shows that the intention to purchase has a positive significant mediating effect in the relationship between renewable energy determinants and use behavior of renewable energy. All results are comparable to those of [6]. In simple words, if positive subjective evaluations of individual behavior increase among the citizens of Nigeria, then the intention to use such energy sources will increase. This will manifest a higher intention to purchase RE among individuals. If purchase intention increases among the citizens of Nigeria, then the use of renewable sources will boost. Hence, according to its indirect effect, improving individuals purchasing intention regarding renewable energy sources can also affect their willingness to use REs by strengthening their attitudes. Finally, the control variables had no significant positive impact on purchase intention.

Table 6. Indirect effects.

\begin{tabular}{cccccc}
\hline Relationships & $\begin{array}{c}\text { Standardized } \\
\text { Indirect } \\
\text { Effects }\end{array}$ & $\begin{array}{c}\text { Standardized } \\
\text { Direct Effects }\end{array}$ & $\begin{array}{c}\text { Standardized } \\
\text { Total Effects }\end{array}$ & $p$ & $\begin{array}{c}\text { Mediation } \\
\text { Result }\end{array}$ \\
\hline $\begin{array}{c}\text { RLA, ATT } \\
\text { and INT }\end{array}$ & 0.073 & 0.148 & 0.222 & 0.001 & $\begin{array}{c}\text { Partial } \\
\text { Mediation } \\
\text { PUN, ATT } \\
\text { and INT }\end{array}$ \\
$\begin{array}{c}\text { PBC, ATT } \\
\text { and INT }\end{array}$ & 0.122 & 0.134 & 0.257 & 0.001 & $\begin{array}{c}\text { Mediation } \\
\text { Partial }\end{array}$ \\
$\begin{array}{c}\text { ITU, ATT } \\
\text { and INT }\end{array}$ & 0.027 & 0.169 & 0.196 & 0.001 & $\begin{array}{c}\text { Mediation } \\
\text { Partial }\end{array}$ \\
$\begin{array}{c}\text { PRI, ATT and } \\
\text { INT }\end{array}$ & -0.057 & 0.087 & 0.122 & 0.001 & $\begin{array}{c}\text { Mediation } \\
\text { Full }\end{array}$ \\
$\begin{array}{c}\text { BRA, ATT } \\
\text { and INT }\end{array}$ & -0.003 & 0.132 & 0.075 & 0.001 & $\begin{array}{c}\text { Mediation } \\
\text { Full }\end{array}$ \\
\hline
\end{tabular}

\section{Conclusions}

This study is based on an extensive review of psychological models, theories, comprehensive frameworks, and various other studies, seeking to identify and investigate individuals' intentions towards renewable energy usage in Nigeria. According to this study's results, the most influential variables influencing individuals to use renewable energy are RE determinants, attitude, and purchase intention. Moreover, there are two mediators in our study; the mediator of attitude has had a significant effect between the determinants of RE and purchase intention. In contrast, purchase intention plays a crucial role in predicting RE's intention to use behavior. This study provided evidence of all the indirect effects of intention to use renewable energy via intellectual processing. This effect can help address our study problem in the field of Nigeria's renewable energy. Finally, 
given that very few studies have been carried to examine the use of such renewable energy in Nigeria, this study not only adds to the strength of the existing literature in the field, but also gives policymakers relevant information that they can put to use to develop RES in rural areas of Nigeria.

\section{Limitations}

Even though the study's findings are consistent with theoretical expectations, the present study has limitations. Firstly, a limited sample size was selected, which has an impact on the generalizability of the results. Second, the data were gathered in households, but did not consider the country's rural and urban parts. In urban and rural areas, socioeconomic characteristics such as awareness, income, and education may vary. Future studies should address this restriction by surveying the countryside. This important component may be taken into account in a future study to enhance the current body of knowledge from a Nigerian viewpoint. Finally, a number of variables influence the RE sector; nevertheless, only the most important ones were examined. This limitation may be addressed by evaluating the effect of other potential variables, such as risk perception, confidence in RETs, and moral responsibilities.

\section{Implications}

This study offers insights into the variables that influence the purchasing intention of sustainable renewable energy. Planners and policymakers may utilize these results to create recommendations to improve renewable energy via renewable energy components, thus impacting society. To that end, organizers should increase the awareness of variables that influence proper usage in order to encourage interest in renewable energy. These awareness campaigns should also emphasize the framework utilized and given in this study to grasp the connections explored here and their consequences for business managers. Helping the environment with renewable energy, which was this study's primary goal, may assist in inducing significant changes in economic growth, and creating a better community.

Author Contributions: Conceptualization, P.C.A. (Paul Chibuogwu Ashinze) and J.T.; methodology, M.N.; software, M.N.; validation, P.C.A. (Paul Chibuogwu Ashinze), J.T. and P.C.A. (Peter Chiedu Ashinze); formal analysis, I.S.; investigation, P.C.A. (Paul Chibuogwu Ashinze); resources, J.T.; data curation, P.C.A. (Paul Chibuogwu Ashinze); writing-original draft preparation, P.C.A. (Paul Chibuogwu Ashinze); writing-review and editing, M.N.; visualization, P.C.A. (Peter Chiedu Ashinze); supervision, J.T.; project administration, J.T.; funding acquisition J.T. All authors have read and agreed to the published version of the manuscript.

Funding: This work was supported by the National Social Science Fund of China under Grant No. 17BGL028.

Institutional Review Board Statement: The study was conducted according to the guidelines of the Declaration, and approved by the Institutional Review Board of School of Economics and Management, Jiangsu University of Science \& Technology, Zhenjiang 212100, China and 8-30-2021).

Informed Consent Statement: Ethical review and approval was not required for the study on human participants in accordance with the local legislation and institutional requirements. Written informed consent to participate in this study was provided by the participants through their supervisors, managers and owners.

Data Availability Statement: The raw data supporting the conclusions of this article will be made available by the authors, without undue reservation, to any qualified researcher.

Conflicts of Interest: The authors declare no conflict of interest.

\section{References}

1. Holdren, J.P.; Morris, G.; Mintzer, I. Environmental aspects of renewable energy sources. Ann. Rev. Energy 1980, 5, 241-291. [CrossRef]

2. He, L.; Chen, Y.; Li, J. A three-level framework for balancing the tradeoffs among the energy, water, and air-emission implications within the life-cycle shale gas supply chains. Resour. Conserv. Recycl. 2018, 133, 206-228. [CrossRef] 
3. Chen, Y.; He, L.; Li, J.; Zhang, S. Multi-criteria design of shale-gas-water supply chains and production systems towards optimal life cycle economics and greenhouse gas emissions under uncertainty. Comput. Chem. Eng. 2018, 109, 216-235. [CrossRef]

4. Wiser, R.H. Green power marketing: Increasing customer demand for renewable energy. Util. Policy 1998, 7, 107-119. [CrossRef]

5. Painuly, J.P. Barriers to renewable energy penetration; a framework for analysis. Renew. Energy 2001, 24, 73-89. [CrossRef]

6. Okedu, K.E.; Uhunmwangho, R.; Wopara, P. Renewable energy in Nigeria: The challenges and opportunities in mountainous and riverine regions. Int. J. Renew. Energy Res. 2015, 5, 222-229.

7. Wole-Osho, I.; Bamisile, O.; Adun, H.; Yusuf, I. Comparison of renewable energy potential in relation to renewable energy policy in ECOWAS countries. In Proceedings of the 2016 HONET-ICT, Nicosia, Cyprus, 13-14 October 2016; pp. $24-28$.

8. Aliyu, A.S.; Dada, J.O.; Adam, I.K. Current status and future prospects of renewable energy in Nigeria. Renew. Sustain. Energy Rev. 2015, 48, 336-346. [CrossRef]

9. Devine-Wright, P. Reconsidering public attitudes and public acceptance of renewable energy technologies: A critical review. In Beyond Nimbyism: A Multidisciplinary Investigation of Public Engagement with Renewable Energy Technologies; University of Manchester: Manchester, UK, 2007; Volume 15.

10. Heaslip, E.; Costello, G.J.; Lohan, J. Assessing good-practice frameworks for the development of sustainable energy communities in Europe: Lessons from Denmark and Ireland. J. Sustain. Dev. Energy Water Environ. Syst. 2016, 4, 307-319. [CrossRef]

11. Huijts, N.M.; Molin, E.J.; Steg, L. Psychological factors influencing sustainable energy technology acceptance: A review-based comprehensive framework. Renew. Sustain. Energy Rev. 2012, 16, 525-531. [CrossRef]

12. Wirtz, J.; Den Ambtman, A.; Bloemer, J.; Horváth, C.; Ramaseshan, B.; Van De Klundert, J.; Canli, Z.G.; Kandampully, J. Managing brands and customer engagement in online brand communities. J. Serv. Manag. 2013, 24, 223-244. [CrossRef]

13. Sambo, A.S. Strategic developments in renewable energy in Nigeria. Int. Assoc. Energy Econ. 2009, 16, 15-19.

14. Sambo, A.S. The place of renewable energy in the Nigerian energy sector. In Proceedings of the World Future Council Workshop on Renewable Energy Policies, Addis Ababa, Ethiopia, 10 October 2009.

15. Abdullahi, D.; Suresh, S.; Renukappa, S.; Oloke, D. Key barriers to the implementation of solar energy in Nigeria: A critical analysis. In Proceedings of the 2nd International Conference on Green Energy Technology (ICGET 2017), IOP Conference Series: Earth and Environmental Science, Rome, Italy, 18-20 July 2017; p. 012015.

16. Adepoju, A.O.; Akinwale, Y.O. Factors influencing willingness to adopt renewable energy technologies among micro and small enterprises in Lagos State Nigeria. Int. J. Sustain. Energy Plan. Manag. 2019, 19, 69-82.

17. Wüstenhagen, R.; Wolsink, M.; Bürer, M.J. Social acceptance of renewable energy innovation: An introduction to the concept. Energy Policy 2007, 35, 2683-2691. [CrossRef]

18. Sesan, T. Status of Renewable Energy Policy and Implementation in Nigeria; Institute of Science and Society, Faculty of Social Sciences, Law and Education, University of Nottingham: Nottingham, UK, 2008.

19. Cheng, X.; He, L.; Lu, H.; Chen, Y.; Ren, L. Optimal water resources management and system benefit for the Marcellus shale-gas reservoir in Pennsylvania and West Virginia. J. Hydrol. 2016, 540, 412-422. [CrossRef]

20. Mi, C.; Huang, Y.; Fu, C.; Zhang, Z.; Postolache, O.; Magazine, M. Vision-Based Measurement: Actualities and Developing Trends in Automated Container Terminals. IEEE Instrum. Meas. Mag. 2021, 24, 65-76. [CrossRef]

21. Dewan, S.; Kraemer, K.L. Information technology and productivity: Evidence from country-level data. Manag. Sci. 2000, 46, 548-562. [CrossRef]

22. Spanos, Y.E.; Prastacos, G.P.; Poulymenakou, A. The relationship between information and communication technologies adoption and management. Inf. Manag. 2002, 39, 659-675. [CrossRef]

23. Malgwi, P.G.; Joshua, W.K. Assessment of the Perception and Awareness of Climate Change and the Influence of Information Amongst Tertiary Education Students in North-East Nigeria. Libr. Inf. Sci. Dig. 2021, 14, 14-24.

24. Ayodele, T.; Ogunjuyigbe, A.; Ajayi, O.; Yusuff, A.; Mosetlhe, T.C. Willingness to pay for green electricity derived from renewable energy sources in Nigeria. Renew. Sustain. Energy Rev. 2021, 148, 111279. [CrossRef]

25. Harland, P.; Staats, H.; Wilke, H.A. Explaining proenvironmental intention and behavior by personal norms and the Theory of Planned Behavior 1. J. Appl. Soc. Psychol. 1999, 29, 2505-2528. [CrossRef]

26. Masukujjaman, M.; Alam, S.S.; Siwar, C.; Halim, S.A. Purchase intention of renewable energy technology in rural areas in Bangladesh: Empirical evidence. Renew. Energy 2021, 170, 639-651. [CrossRef]

27. Ajzen, I. From intentions to actions: A theory of planned behavior. In Action Control; Springer: Berlin/Heidelberg, Germany, 1985; pp. 11-39.

28. Rezaei, R.; Ghofranfarid, M. Rural households' renewable energy usage intention in Iran: Extending the unified theory of acceptance and use of technology. Renew. Energy 2018, 122, 382-391. [CrossRef]

29. Chen, T.B.; Chai, L.T. Attitude towards the environment and green products: Consumers' perspective. Manag. Sci. Eng. 2010, 4, 27-39.

30. Alam, S.S.; Hashim, N.H.N.; Rashid, M.; Omar, N.A.; Ahsan, N.; Ismail, M.D. Small-scale households renewable energy usage intention: Theoretical development and empirical settings. Renew. Energy 2014, 68, 255-263. [CrossRef]

31. Ajzen, I. The theory of planned behavior. Organ. Behav. Hum. Decis. Process. 1991, 50, 179-211. [CrossRef]

32. Feng, H.-Y. Key factors influencing users' intentions of adopting renewable energy technologies. Acad. Res. Int. 2012, 2, 156.

33. Ahmad, A.; Rashid, M.; Omar, N.A.; Alam, S.S. Perceptions on renewable energy use in Malaysia: Mediating role of attitude. Jurnal Pengurusan UKM J. Manag. 2014, 41. [CrossRef] 
34. Ostlund, L.E. Factor analysis applied to predictors of innovative behavior. Decis. Sci. 1973, 4, 92-108. [CrossRef]

35. Moore, G.C.; Benbasat, I. Development of an instrument to measure the perceptions of adopting an information technology innovation. Inf. Syst. Res. 1991, 2, 192-222. [CrossRef]

36. Li, J.; Wang, F.; He, Y. Electric vehicle routing problem with battery swapping considering energy consumption and carbon emissions. Sustainability 2020, 12, 10537. [CrossRef]

37. Silva, C.E.T. Factors Influencing the Development of Local Renewable Energy Strategies; Lund University: Lund, Sweden, 2008.

38. Mallett, A. Social acceptance of renewable energy innovations: The role of technology cooperation in urban Mexico. Energy Policy 2007, 35, 2790-2798. [CrossRef]

39. Zahari, A.R.; Esa, E. Motivation to adopt renewable energy among generation Y. Procedia Econ. Financ. 2016, 35, 444-453. [CrossRef]

40. Alam, S.S.; Rashid, M. Intention to use renewable energy: Mediating role of attitude. Energy Res. J. 2012, 3, 37-44. [CrossRef]

41. Venkatesh, V.; Morris, M.G.; Davis, G.B.; Davis, F.D. User acceptance of information technology: Toward a unified view. MIS Q. 2003, 27, 425-478. [CrossRef]

42. Fishbein, M.; Ajzen, I. Belief, attitude, intention, and behavior: An introduction to theory and research. Philos. Rhetor. 1977, 10, 177-188.

43. Bang, H.K.; Ellinger, A.E.; Hadjimarcou, J.; Traichal, P.A. Consumer concern, knowledge, belief, and attitude toward renewable energy: An application of the reasoned action theory. Psychol. Mark. 2000, 17, 449-468. [CrossRef]

44. Wang, X.; Pacho, F.; Liu, J.; Kajungiro, R. Factors influencing organic food purchase intention in developing countries and the moderating role of knowledge. Sustainability 2019, 11, 209. [CrossRef]

45. Lee, K. Gender differences in Hong Kong adolescent consumers' green purchasing behavior. J. Consum. Mark. 2009, 26, 87-96. [CrossRef]

46. Salazar, H.A.; Oerlemans, L.; van Stroe-Biezen, S. Social influence on sustainable consumption: Evidence from a behavioural experiment. Int. J. Consum. Stud. 2013, 37, 172-180. [CrossRef]

47. Tsarenko, Y.; Ferraro, C.; Sands, S.; McLeod, C. Environmentally conscious consumption: The role of retailers and peers as external influences. J. Retail. Consum. Serv. 2013, 20, 302-310. [CrossRef]

48. Ajzen, I. Perceived behavioral control, self-efficacy, locus of control, and the theory of planned behavior 1. J. Appl. Soc. Psychol. 2002, 32, 665-683. [CrossRef]

49. Yazdanpanah, M.; Komendantova, N.; Ardestani, R.S. Governance of energy transition in Iran: Investigating public acceptance and willingness to use renewable energy sources through socio-psychological model. Renew. Sustain. Energy Rev. 2015, 45, 565-573. [CrossRef]

50. Hassan, M.N.A.; Pozi, F.M.; Almsafir, M.K.; Alias, R. Exploring environmental behavior at green office building using Theory of Planned Behavior. In Proceedings of the 3rd National Graduate Conference (NatGrad2015), Universiti Tenaga Nasional, Putrajaya, Malaysia, 8-9 April 2015.

51. Wiser, R. Green Marketing, Renewables, and Free Riders: Increasing Customer Demand for a Public Good. 1997. Available online: https: / / www.osti.gov/servlets / purl/645498 (accessed on 25 July 2021).

52. Davis, F.D. Perceived usefulness, perceived ease of use, and user acceptance of information technology. MIS Q. 1989, 13, 319-340. [CrossRef]

53. Komendantova, N.; Patt, A.; Barras, L.; Battaglini, A. Perception of risks in renewable energy projects: The case of concentrated solar power in North Africa. Energy Policy 2012, 40, 103-109. [CrossRef]

54. Haidar, A.M.; John, P.N.; Shawal, M. Optimal configuration assessment of renewable energy in Malaysia. Renew. Energy 2011, 36, 881-888. [CrossRef]

55. Menegaki, A.N. A social marketing mix for renewable energy in Europe based on consumer stated preference surveys. Renew. Energy 2012, 39, 30-39. [CrossRef]

56. Sidiras, D.K.; Koukios, E.G. Solar systems diffusion in local markets. Energy Policy 2004, 32, 2007-2018. [CrossRef]

57. Hartmann, P.; Ibáñez, V.A. Managing customer loyalty in liberalized residential energy markets: The impact of energy branding. Energy Policy 2007, 35, 2661-2672. [CrossRef]

58. Faiers, A.; Neame, C. Consumer attitudes towards domestic solar power systems. Energy Policy 2006, 34, 1797-1806. [CrossRef]

59. Ansolabehere, S.; Konisky, D.M. Public attitudes toward construction of new power plants. Public Opin. Q. 2009, 73, 566-577. [CrossRef]

60. Premkumar, G.; Ramamurthy, K.; Crum, M. Determinants of EDI adoption in the transportation industry. Eur. J. Inf. Syst. 1997, 6, 107-121. [CrossRef]

61. Kardooni, R.; Yusoff, S.B.; Kari, F.B. Renewable energy technology acceptance in Peninsular Malaysia. Energy Policy 2016, 88, 1-10. [CrossRef]

62. Fornara, F.; Pattitoni, P.; Mura, M.; Strazzera, E. Predicting intention to improve household energy efficiency: The role of valuebelief-norm theory, normative and informational influence, and specific attitude. J. Environ. Psychol. 2016, 45, 1-10. [CrossRef]

63. Chen, M.-F.; Lin, Y.-P.; Cheng, T.-J. Public attitudes toward nanotechnology applications in Taiwan. Technovation 2013, 33, 88-96. [CrossRef]

64. Mirza, U.K.; Ahmad, N.; Harijan, K.; Majeed, T. Identifying and addressing barriers to renewable energy development in Pakistan. Renew. Sustain. Energy Rev. 2009, 13, 927-931. [CrossRef] 
65. McEachern, M.; Seaman, C.; Padel, S.; Foster, C. Exploring the gap between attitudes and behaviour. Br. Food J. 2005, 107, 606-625.

66. Babalola, Y.T.; Babalola, A.D.; Okhale, F.O. Awareness and accessibility of environmental information in Nigeria: Evidence from Delta State. Libr. Philos. Pract. 2010, 460, 1-6.

67. Batley, S.L.; Colbourne, D.; Fleming, P.; Urwin, P. Citizen versus consumer: Challenges in the UK green power market. Energy Policy 2001, 29, 479-487. [CrossRef]

68. He, L.; Chen, Y.; Zhao, H.; Tian, P.; Xue, Y.; Chen, L. Game-based analysis of energy-water nexus for identifying environmental impacts during Shale gas operations under stochastic input. Sci. Total Environ. 2018, 627, 1585-1601. [CrossRef]

69. Kotler, P.; Keller, K. Marketing Management New Jersey, 11th ed.; Prentica Hall: Hoboken, NJ, USA, 2003.

70. Saleh, A.M.; Haris, A.B.; Bint Ahmad, N. Towards a UTAUT-based model for the intention to use solar water heaters by Libyan households. Int. J. Energy Econ. Policy 2014, 4, 26.

71. Park, E.; Ohm, J.Y. Factors influencing the public intention to use renewable energy technologies in South Korea: Effects of the Fukushima nuclear accident. Energy Policy 2014, 65, 198-211. [CrossRef]

72. Fox-Cardamone, L.; Hinkle, S.; Hogue, M. The correlates of antinuclear activism: Attitudes, subjective norms, and efficacy. $J$. Appl. Soc. Psychol. 2000, 30, 484-498. [CrossRef]

73. Paladino, A.; Baggiere, J. Are we "green"? An empirical investigation of renewable electricity consumption. ACR Eur. Adv. 2008, 8, 340-341.

74. Yang, S.; Zhao, D. Do subsidies work better in low-income than in high-income families? Survey on domestic energy-efficient and renewable energy equipment purchase in China. J. Clean. Prod. 2015, 108, 841-851. [CrossRef]

75. Zorić, J.; Hrovatin, N. Household willingness to pay for green electricity in Slovenia. Energy Policy 2012, 47, 180-187. [CrossRef]

76. Al Mamun, A.; Mohamad, M.R.; Yaacob, M.R.B.; Mohiuddin, M. Intention and behavior towards green consumption among low-income households. J. Environ. Manag. 2018, 227, 73-86. [CrossRef]

77. Mainieri, T.; Barnett, E.G.; Valdero, T.R.; Unipan, J.B.; Oskamp, S. Green buying: The influence of environmental concern on consumer behavior. J. Soc. Psychol. 1997, 137, 189-204. [CrossRef]

78. Lai, P. The literature review of technology adoption models and theories for the novelty technology. JISTEM-J. Inf. Syst. Technol. Manag. 2017, 14, 21-38. [CrossRef]

79. Wandiga, E.N.; Kilika, J.M.; James, R. Linking Operations Strategies with Customer Based Competence and Firm Performance in the Context of Knowledge Based Intensive Sector: A Theoretical Review. Int. J. Bus. Manag. 2017, 12, 234-248. [CrossRef]

80. Maichum, K.; Parichatnon, S.; Peng, K.-C. Application of the extended theory of planned behavior model to investigate purchase intention of green products among Thai consumers. Sustainability 2016, 8, 1077. [CrossRef]

81. Aristio, A.P.; Supardi, S.; Hendrawan, R.A.; Hidayat, A.A. Analysis on Purchase Intention of Indonesian Backpacker in Accommodation Booking through Online Travel Agent. Procedia Comput. Sci. 2019, 161, 885-893. [CrossRef]

82. Liobikienè, G.; Mandravickaitè, J.; Bernatonienè, J. Theory of planned behavior approach to understand the green purchasing behavior in the EU: A cross-cultural study. Ecol. Econ. 2016, 125, 38-46. [CrossRef]

83. Kim, Y.; Han, H. Intention to pay conventional-hotel prices at a green hotel-a modification of the theory of planned behavior. $J$. Sustain. Tour. 2010, 18, 997-1014. [CrossRef]

84. Hoang, X.L.; Nguyen, T.K.C.; Ly, H.M.; Luong, T.T.; Nguyen, T.T.Q. The moderating role of csr associations on the link between brand awareness and purchase intention. J. Asian Financ. Econ. Bus. 2020, 7, 233-240. [CrossRef]

85. Wang, Y.-H.; Chen, L.-Y. An empirical study of the effect of perceived price on purchase intention evidence from low-cost carriers. Int. J. Bus. Soc. Sci. 2016, 7, 97-107.

86. Zhang, L.; Chen, L.; Wu, Z.; Zhang, S.; Song, H. Investigating young consumers' purchasing intention of green housing in China. Sustainability 2018, 10, 1044. [CrossRef]

87. Anderson, J.C.; Gerbing, D.W. Structural equation modeling in practice: A review and recommended two-step approach. Psychol. Bull. 1988, 103, 411. [CrossRef]

88. Hair, B.; Black, C.; Babin, A. Multivariate Data Analysis; Pearson Prentice Hall: Hoboken, NJ, USA, 2010.

89. Fornell, C.; Larcker, D.F. Evaluating structural equation models with unobservable variables and measurement error. J. Mark. Res. 1981, 18, 39-50. [CrossRef]

90. Nunnally, J.C. An overview of psychological measurement. In Clinical Diagnosis of Mental Disorders; Springer: Berlin/Heidelberg, Germany, 1978; pp. 97-146.

91. Irfan, M.; Hao, Y.; Ikram, M.; Wu, H.; Akram, R.; Rauf, A. Assessment of the public acceptance and utilization of renewable energy in Pakistan. Sustain. Prod. Consum. 2021, 27, 312-324. [CrossRef] 